\title{
Fen Bilimleri Dersindeki Madde ve Değişim Ünitesine Yönelik Geçerli ve Güvenilir Başarı Testi Geliştirme: BİLSEM Örneği
}

\author{
Developing a Valid and Reliable Achievement Test for Matter and Change Unit in Science \\ Course: Example of BİLSEM
}

\section{Oğuzhan NACAROĞLU1 ${ }^{1}$ Oktay BEKTAŞ²}

\author{
${ }^{1}$ Doktora Öğrencisi, Erciyes Üniversitesi, onacaroglu44@gmail.com, iD 0000-0001-8516-9152 \\ ${ }^{2}$ Doç. Dr., Erciyes Üniversitesi, Eğitim Fakültesi, obektas@erciyes.edu.tr, (D)0000-0002-2562-2864
}

\begin{tabular}{|c|c|c|c|c|}
\hline \multicolumn{5}{|c|}{ Araştırma makalesi/ Research Article } \\
\hline Geliş: 15.10.2019 & 䄅 & Kabul: 26.11.2019 & 慗 & Yayın: 31.12.2019 \\
\hline
\end{tabular}

Atıf

Nacaroğlu, O. \& Bektaş, O. (2019). Fen bilimleri dersindeki madde ve değişim ünitesine yönelik geçerli ve güvenilir başarı testi geliştirme: BİLSEM örneği. Maarif Mektepleri Uluslararası Eğitim Bilimleri Dergisi, 3(2), 67-88.

Nacaroğlu, O. \& Bektaş, O. (2019). Developing a valid and reliable achievement test for matter and change unit in science course: Example of BILLSEM. Maarif Mektepleri International Journal of Educational Sciences, 3(2), 67-88.

Öz

$\mathrm{Bu}$ çalışmada, Bilim ve Sanat Merkezlerinde yürütülen fen bilimleri dersindeki "Madde ve Değişim" ünitesine yönelik geçerli ve güvenilir bir başarı testinin geliştirilmesi amaçlanmıştır. Araştırmada nicel araştırma yöntemi desenlerinden tarama kullanılmıştır. Araştırmanın örneklemini, Doğu Anadolu Bölgesi'nde yer alan bir Bilim ve Sanat Merkezi'nde öğrenimlerine devam eden 115 özel yetenekli öğrenci oluşturmaktadır. Başarı testi geliştirme sürecinde öncelikle alan yazın taranmış ve ünite kazanımlarına uygun sorular belirlenmiştir. Başarı testinin kapsam geçerliğini sağlamak için belirtke tablosu hazırlanmış ve uzman görüşleri alınmıştır. Her bir kazanıma yönelik en az iki soru içeren test, örneklemde yer alan özel yetenekli öğrencilere pilot çalışma olarak uygulanmıştır. Elde edilen veriler SPSS 20 paket programı ve Excel kullanılarak analiz edilmiştir. Her bir soru maddesi için madde güçlük ve ayırt edicilik indeksleri hesaplanmıştır. Bu süreç sonunda bir sorunun testten çıkarılmasına karar verilmiştir. Güvenirlik hesaplamaları sonucunda KR20 iç tutarlık katsayısı .87 olarak hesaplanmış ve faktör analizi sonucunda testin 5 faktörlü bir 
yapıya sahip olduğu bulunmuştur. Elde edilen bulgular ışığında özel yetenekli öğrencilerin madde ve değişim ünitesine yönelik başarı düzeylerini belirlemek amacıyla geliştirilen 34 çoktan seçmeli sorudan oluşan testin geçerli ve güvenilir olduğu ifade edilebilir.

Anahtar Kelimeler: Fen bilimleri, madde ve değişim, başarı testi, özel yetenekli öğrenci

\section{Abstract}

In this research, it was aimed to develop a valid and reliable achievement test for matter and change unit in science course conducted in Science and Art Centers. In the research, survey, quantitative research method, designs was used. The sample of the study consisted of 115 gifted students studying at a Science and Art Center in the Eastern Anatolia Region. In the development of achievement test, firstly, the literature was examined and questions which were suitable for unit gains were determined. In order to ensure the scope validity of the achievement test, a table of specifications was prepared and expert opinions were obtained. The test, which contained at least two questions for each acquisition, was applied as a pilot study to the gifted students in the sample. Item difficulty and discrimination indexes were calculated for each question item. At the end of this process, it was decided to remove a problem from the test. As a result of the reliability calculations, KR20 internal consistency coefficient was calculated as .87 and as a result of factor analysis, it was determined that consisted of 5-factor. In the light of the findings, it can be stated that the test developed to determine the achievement level of the gifted students for the matter and change unit is valid and reliable.

Keywords: Science course, matter and change, achievement test, gifted students

\section{Giriş}

Bilim ve sanayide meydana gelen değişimler, eğitim sisteminin de değişmesine neden olmuştur. Bu değişim, öğrencilerin var olan bilgileri almasından ziyade, bilgiyi üretmesini ve kullanmasını zorunlu kılmıştır. Yaşantıları sayesinde bireylerin davranışlarında istendik değişimleri sağlama sürecini ifade eden eğitimin (Gültekin, 2017), bu davranışları kazandırmada etki düzeyinin belirlenmesi ve bireyin davranışlarında nasıl değişimler meydana getirdiğinin incelenmesi gerekmektedir (Keçeci, Yıldırım ve Kırbağ-Zengin, 2019). Bu amaç doğrultusunda öğrencilerin süreç içerisinde karşılaştıkları bilgilerin ne kadarını kazandıklarının tespiti noktasında akademik başarılarının belirlenmesi (Bingöl ve Halisdemir, 2017), dolayısıyla uygun ölçme ve değerlendirme işlemlerinin yapılması önem arz etmektedir (Öksüz ve Güven-Demir, 2019; Samaie ve Khosravian, 2014).

Ölçme bir özelliğin gözlemlenmesi ve elde edilen sonuçların sembollerle ifade edilmesi (Turgut ve Baykul, 2012), değerlendirme ise ölçülen nitelik hakkında bir ölçüt çerçevesinde karar verme sürecidir (Turgut,1983). Diğer derslerde olduğu gibi fen bilimleri derslerinde de öğrenci başarılarının ölçülmesi ve değerlendirilmesi kapsamında farklı ölçme araçları kullanılmaktadır (Güngörmez ve Akgün, 2018). Bu ölçme araçlarına; sözlü sinavlar, boşluk doldurmalı testleri, açık uçlu sorular, doğru yanlış testleri, yazılı yoklamalar, iki aşamalı testler, çoktan seçmeli, kısa yanıtlı testler örnek olarak verilebilir (Kempa, 1986; Şimşek, 2009). Bu testlerden eğitim sürecinde en çok kullanılan ve öğrencilerin çoğunlukla akademik başarı ve kavram 
yanılgılarının tespitinde tercih edilen ölçme aracı, çoktan seçmeli testlerdir (Güngörmez ve Akgün, 2018; Haladyna, 1997; Küçükahmet. 2002).

Çoktan seçmeli testler, doğru cevabın seçenekler arasına gizlendiği ve bu seçenekler arasından öğrencilerden doğru cevabın işaretlenmesinin istendiği testlerdir (Güler, 2017). Öğrenci sayısının fazla olduğu gruplarda puanlama güvenirliğini sağlamak için uygun olan çoktan seçmeli testlerin (Klufa, 2015); çabuk puanlanabiliyor olması (Birgili, 2014), nesnel puanlamaya imkân vermesi (Turgut ve Baykul, 2012), kapsam geçerliliğini sağlamada kullanışlı olması (Güler, 2017) gibi birçok faydası bulunmaktadır. Her ölçme aracının güçlü ve zayıf yönleri olmakla birlikte çoktan seçmeli testlerin, öğrencilerin bilgi düzeylerini ortaya çıarmada sözlü sinavlardan sonra en sık kullanılan testler olduğu görülmektedir (Ogan-Bekiroğlu, 2004). Bununla birlikte bir konuya ait uygun başarı testinin geliştirilebilmesi için bazı adımların takip edilmesi gerekmektedir (Ersoy ve Bayraktar, 2018).

Başarı testi geliştirme sürecinde; amaç ve kapsamın belirlenmesi, testin geçerlik ve güvenirlik çalışmalarının yapılması büyük bir öneme sahiptir (Balcı ve Tekkaya, 2000; Güneş-Yazar ve Nakipoğlu, 2019). Geçerlilik, geliştirilen başarı testinin ölçülmek istenen özelliği ne derecede ölçtügünü, güvenirlik ise başarı testinde yer alan maddelere verilen cevaplar arasındaki tutarlılığı belirtir (Büyüköztürk, 2018). Başarı testinin amacının belirlenmesi, öğretim programlarının incelenmesi, konu kazanımlarına uygun soru havuzunun oluşturulması, hedef kitleye aday başarı testinin uygulanması, gerekli madde analizlerinin yapılması gibi süreçler düşünüldüğünde başarı testi hazırlama sürecinin emek gerektiren bir süreç olduğu görülmektedir (Güneş-Yazar ve Nakipoğlu, 2019). Bununla birlikte test geliştirme sürecinde uygun taksonomik basamakların belirlenmesi de gerekmektedir. Alan yazın incelendiğinde, Bloom ve Haladyna taksonomilerinin test geliştirme çalışmalarında yer aldığı görülmekte olup (Kempa, 1986) Haladyna taksonomisinde; anlama, problem çözme, eleştirel düşünme ve yaratıcılık basamakları yer almaktadır (Haladyna, 1997). Bilim ve Sanat Merkezlerinde (BİLSEM) Bireysel Yetenekleri Fark Ettirme (BYF) programında öğrenim gören özel yetenekli öğrencilerin fen bilimleri dersi Madde ve Değişim ünitesine yönelik öğrenme düzeylerini belirlemek için geçerli ve güvenilir bir başarı testi geliştirme çalışmaları kapsamında Haladyna'nın (1997) felsefesi dikkate alınmıştır. Bu kapsamda başarı testi geliştirme sürecinde çalışmanın odak noktasını BİLSEM'de öğrenimlerine devam eden özel yetenekli öğrenciler oluşturmaktadır.

BİLSEM'ler, özel yetenekli öğrencilerin devam ettikleri okullarını aksatmayacak bir şekilde yeteneklerinin farkına varmaları, kapasitelerini geliştirmeleri ve bu kapasitelerini en üst düzeyde kullanmaları amacıyla açılmış olan özel eğitim kurumlarıdır (MEB, 2017a). Özel yetenekli öğrencilerin sahip oldukları özelliklerinin farkına varmaları ve ilerleyen süreçte faydalı işler yapabilmeleri için bu öğrencilerin erken yaşta teşhis edilmesi önem arz etmektedir. Bu kapsamda BİLSEM'lere giriş yapabilmek için 1. 2. ve 3. sınıfta olan ve sınıf öğretmenleri tarafından önerilen öğrencilerin iki aşamalı sınavdan geçmesi gerekmektedir (Sarıtaş, Şahin ve Çatalbaş, 
2019). Bu sınavlardan başarılı olan öğrenciler, hafta içi ya da hafta sonu örgün eğitimlerini aksatmayacak bir şekilde BİLSEM'deki eğitim faaliyetlerine katılırlar. Bu faaliyetler; Uyum Eğitimi, Destek Eğitimi, Bireysel Yetenekleri Fark Ettirme (BYF), Özel Yetenekleri Geliştirme (ÖYG) ve Proje Üretimi-Yönetimi programları dikkate alınarak yürütülmektedir (Kayışdağ ve Melekoğlu, 2019).

Uyum eğitim programı BİLSEM sınavlarını kazanan öğrencilere; kurumun amaçlarının, yapı ve işleyişinin, öğretmen kadrosunun, yapılacak faaliyetlerin tanıtıldı̆̆ 1 programdır. Uyum eğitimi ile öğrencilerin BİLSEM'e adapte olması amaçlanır. Destek eğitiminde, disiplinler arası çalışma dikkate alınarak öğrencilerin temel becerileri kazanması hedeflenir. Destek eğitiminde başarı gösteren öğrenciler BYF programına alınır. Bu programda, öğrencilerin yeteneklerinin farkına varmalarını sağlamak, ilerleyen süreçte ciddi çalışmalar yapmak isteyeceği alanları belirlemek, çalışmak isteyeceği alana yönelik olarak tutum ve becerilerinin farkına varmalarını sağlamak amaçlanır (Ayverdi, 2018). BYF programını tamamlayan öğrenciler ÖYG programına alınır. Bu programda öğrenciler özel yeteneklerine yönelik bilimsel ve sanatsal faaliyetler yürütürler. Bu programı da başarı ile bitiren öğrenciler, proje üretimi ve yönetimi programı çerçevesinde çalışmalarını danışman öğretmenlerin gözetiminde daha ileri bir seviyeye taşırlar (MEB, 2016c). Tüm bu değerlendirmeler ışığında BİLSEM'lerde özel yetenekli öğrenciler için örgün eğitim kurumlarından farklı ve zenginleştirilmiş bir program uygulanmakta olup bu öğrencilerin öğrenme düzeylerinin tespiti için uygun ve kullanışlı bir başarı testinin geliştirilmesi önem arz etmektedir. Çünkü eğitim sürecinde elde edilen verilerin anlamlı olabilmesi, öğrencinin gelişiminin izlenmesi ve yönlendirilmesi noktasında geçerli ve güvenilir çoktan seçmeli testlerin kullanılması gerekmektedir (Saraç ,2018). $\mathrm{Bu}$ kapsamda BYF programında öğrenim gören özel yetenekli öğrencilerin fen bilimleri dersi Madde ve Değişim ünitesindeki başarılarını belirlemek için geçerli ve güvenilir bir başarı testi geliştirilmesi amaçlanmıştır. Fen eğitiminde yapılan araştırmalar incelendiğinde; Enerji ve Momentum (Singh ve Rosengrant, 2003), Isı ve Sıcaklık (Ayvacı ve Durmuş, 2016), Güneş Sistemi (Gülen ve Demirkuş, 2014), İş ve Enerji (Açıkgöz ve Karslı, 2015), Kuvvet ve Hareket (Akbulut ve Çepni, 2013), Hücre Bölünmesi ve Kalıtım (Kızkapan ve Bektaş, 2018) gibi farklı konulara yönelik başarı testlerinin geliştirildiği görülmektedir. Bununla birlikte alan yazında Madde ve Değişim ünitesine yönelik başarı testi geliştirme çalışmalarının yeterli sayıda olmadığ1 tespit edilmiştir (Saraç, 2018). Bu bakımdan çalışmanın alan yazına katkı sağlayacağı düşünülmektedir. Ayrıca çalışma, BYF programında öğrenim gören özel yetenekli öğrencilere yönelik yürütülen fen eğitimindeki Madde ve Değişim ünitesini kapsaması bakımından diğer çalışmalardan farklılık göstermektedir. Belirlenen amaç doğrultusunda aşağıda yer alan araştırma sorularına cevap aranmıştır:

1. BYF programında öğrenim gören özel yetenekli öğrencilerin "Madde ve Değişim" ünitesindeki başarılarını belirlemek için hazırlanan çoktan seçmeli test geçerli midir? 
2. BYF programinda öğrenim gören özel yetenekli öğrencilerin "Madde ve Değişim" ünitesindeki başarılarını belirlemek için hazırlanan çoktan seçmeli test güvenilir midir?

\section{Yöntem}

\section{Araştırma Modeli}

Bu çalışma, nicel araştırma yöntemi desenlerinden tarama deseni kullanılarak yürütülmüştür. Tarama deseni, diğer desenlere göre büyük örneklemler üzerinde yürütülür ve bir konu ya da olay hakkında katılımcıların ilgi, beceri, görüş, yetenek gibi niteliklerinin ortaya çıkarıldığı bir desendir (Fraenkel ve Wallen, 2006). Bu kapsamda, BYF programında öğrenim gören özel yetenekli öğrencilerin Madde ve Değişim ünitesindeki başarı düzeylerini belirlemek amacıyla geçerli ve güvenilir bir başarı testi geliştirilmesi çalışmasında tarama deseni kullanılmıştır.

\section{Evren ve Örneklem}

Çalışmanın ulaşılabilir evrenini 2018-2019 eğitim öğretim döneminde Doğu Anadolu Bölgesi'nde yer alan bir BİLSEM'de öğrenimlerine devam eden özel yetenekli öğrenciler, çalışmanın örneklemini ise bu BİLSEM'de Madde ve Değişim ünitesini gören 115 özel yetenekli öğrenci oluşturmaktadır. Ulaşılabilir evrene genelleme yapabilmek adına öğrencilerin en az \%10'una ulaşılmaya çalışılmıştır. Ayrıca katılımcıların 52'si kadın, 63'ü erkek öğrencilerden oluşmaktadır. Çalışmanın örnekleminin belirlenmesinde küme örnekleme yöntemi tercih edilmiştir (Büyüköztürk, Kılıç Çakmak, Akgün, Karadeniz ve Demirel, 2014). Küme örnekleme, evrenden seçilen kümeler üzerinde yapılır ve evrendeki bütün kümeler eşit seçilme şansına sahiptir (Karasar, 1995).

\section{Veri Toplama Araçları}

Bu çalışmada, BYF programı Madde ve Değişim ünitesinde düzey belirlemeye yönelik bir başarı testini veri toplama aracı olarak geliştirmek amaçlanmıştır. Başarı testi oluşturulurken geçerlik ve güvenirlik çalışmaları yapılmış ve bulgular ilgili bölümde sunulmuştur.

\section{Verilerin Analizi}

Başarı testinin geliştirilmesi sürecinde gerekli geçerlik ve güvenirlik çalışmalarını yapmak için öncelikle belirlenen örnekleme ulaşılmaya çalışılmış ve hazırlanan başarı testi uygulanmıştır. Uygulama aşamasından sonra her bir forma numaralar verilmiş ve katılımcıların cevap formları rubrik kullanılarak okunmuştur. Öğrencilerin doğru cevaplarına " 1 ", boş ve yanlış cevaplarına " 0 " değeri verilmiş olup tüm soruları doğru cevaplayan öğrencinin alabileceği maksimum puan 35, hiçbirini doğru cevaplayamayan öğrencinin alabileceği puan ise sıfır (0)'dır. Kâğıtlara gerekli puanlamalar yapıldıktan sonra SPSS 22 paket programina 
öğrencilerin verdikleri cevaplar sırasıyla girilmiştir. Kapsam geçerliğini sağlamak için sırasıyla; çalışmanın amacının belirlenmesi ve kazanımların oluşturulması, soru havuzunun oluşturulması, belirtke tablosunun hazırlanması, bu süreçte uzman kontrolünün sağlanması, ayrıca soru hazırlama süreci ile kazanımların belirlemesinde taksonomik kurallara dikkat edilmesi gibi çalışmalar yapılmıştır. Testin geçerliğine hizmet etmesi adına güçlük ve ayırt edicilik indeksleri incelenmiştir. Bu kapsamda, öğrencilerin aldığı puanlar sıralandıktan sonra \%27'lik alt grup ile \%27'lik üst grup belirlenmiştir. Yapı geçerliğini sağlamak için açımlayıcı faktör analizi yürütülmüştür. Daha sonra KR 20 güvenirlik katsayısı hesaplanmıştır. Çalışma başarı testi geliştirme basamaklarına uygun olarak yürütüldüğü için analize dair detaylı bilgilere bulgular kısmında yer verilmiştir.

\section{Bulgular}

\section{Başarı Testine Yönelik Geçerlik Çalışması}

Geçerlik, bir amaç doğrultusunda hazırlanan testin amaca hizmet etme derecesi veya zihinsel süreçleri ölçme derecesi olarak ifade edilebilir (Fraenkel ve Wallen, 1996). Bu kısımda geçerlik çalışması yönelik bulgular sunulmuştur. Başarı testi soruları hazırlama sürecinde gerekli alan yazın taraması yapılmış (Bağcaz, 2009; Çakır, 2011; Gökçek, 2007; Kaşmer, 2011; Nur-Aydın, 2018) ve araştırmalardan elde edilen sorularla birlikte bir soru havuzu oluşturulmuştur. BYF programı Madde ve Değişim ünitesi kazanımları incelenmiş fen eğitiminde uzman iki kişinin görüşleriyle birlikte kazanımlar belirlenmiştir. Kazanımlar anlama, problem çözme, eleştirel düşünme ve yaratıcılık şeklinde dört adet üst düzey düşünme becerileri içeren Haladyna (1997) taksonomisi dikkate alınarak yazılmıştır. Bu taksonomik basamaklardan anlama basamağında; tanım, hatırlama ve ezber şeklinde nitelendirilen sorular yer alırken, problem çözme basamağında bir problemin çözümünü isteyen sorular bulunmaktadır. Bununla birlikte eleştirel düşünme basamağındaki sorular öğrencinin analiz ve değerlendirme yapabileceği sorular yer alırken, yaratıcılık basamağında ise öğrenci sorunun çözümünde bir ürün ortaya koyması önem arz etmektedir. Buradan hareketle ünite kapsamında kazanımlar belirlenmiş ve bu kazanımların Haladyna'nın (1997) düşünme süreçleri ve sorulara göre dağılımı Tablo 1'de verilmiştir. Kapsam geçerliğini sağlamak adına belirtke tablosu hazırlanmıştır.

Tablo 1. Başarı testine ait belirtke tablosu

\begin{tabular}{|c|c|c|c|c|}
\hline \multirow[b]{2}{*}{$\begin{array}{c}\text { Soru } \\
\text { no }\end{array}$} & \multirow[b]{2}{*}{ Kazanımlar } & \multicolumn{3}{|c|}{ Bilişsel (Zihinsel) düzey } \\
\hline & & Anlama & $\begin{array}{c}\text { Problem } \\
\text { çözme }\end{array}$ & $\begin{array}{l}\text { Eleştirel } \\
\text { düşünme }\end{array}$ \\
\hline 1 & Çizilen modellerden elementlere ait olan modeli bulur. & & $x$ & \\
\hline 2 & Periyodik sistemde elementlerin benzer özelliklerine göre & $X$ & & \\
\hline
\end{tabular}


sınıflandırıldı̆̆ını bilir.

3

İlk 20 elemente yönelik art arda gelen elementleri üçerli olarak siniflar.

$4 \quad$ Elementlere yönelik olarak çizilen modelleri bulur.

$5 \quad$ Bazı elementlerin periyodik sistemdeki yerlerini tahmin eder.

6 Maddelerin fiziksel ve kimyasal özelliklerini analiz eder.

7 Maddelerin $\mathrm{pH}$ değerlerini kullanarak asitlik ve bazlık durumları hakkında çıkarımda bulunur.

8 Kimyasal tepkimenin gerçekleştiğini gösteren durumları bilir.

9 Asit ve bazların özelliklerini karşılaştırır.

10 İlk 20 elementin günlük hayattaki kullanım alanlarını bilir

11 İlk 20 elementi metal ve ametal olarak sınıflandırır.

12 İlk 20 elementin ve yaygın elementlerin isim - sembol eşleştirmeleri yapar.

13 Turnosol kağıdının renk değiştirme özelliğini çözeltiler üzerinde kullanır.

14 Kimyasal değişimi farklı bir olay üzerinden açıklar.

Günlük hayatta meydana gelen fiziksel ve kimyasal değişimleri ayırt eder.

16

Günlük hayatta meydana gelen fiziksel ve kimyasal değişimleri ayırt eder.

17

Suyun elektrik enerjisi kullanılarak bileşenlerine ayrılmasını kavrar.

18 Elektroliz olayı için gerekli olan malzemeleri tanır.
$X$

$X$

$\mathbf{X}$

$\mathbf{X}$

$\mathbf{X}$

$X$

$X$

X

$X$

$X$

$X$

X

X

X

X

X

$X$

$X$

$X$ 
örnekler verir.

24 Elementleri metal, ametal yarı metal olarak sınıflandırır.

$\mathrm{X}$

$\mathbf{X}$

25 Elektroliz olayını mikroskobik düzeyde yorumlar.

26 Gümüş halojenür bileşiklerini bilir.

$\mathrm{X}$

27 Gümüş halojenür bileşiklerinin teknolojide kullanım alanlarını değerlendirir.

28 Belirli özellikte madde yapmak için ilk 20 elementten hangi elementi kullanacağına karar verir.

29 Element ve sembollerini kullanarak bir bulmacayı çözer.

30 Belirteçlerin özelliklerini kullanarak asit olan çözeltiyi seçer.

31 Bazların genel özelliklerini bilir.

32 Günlük hayatta fiziksel değişime örnekler verir.

33

Belirteç olan turnusol kâğıdının asit ve bazlar üzerindeki etkisini anlar.

34

Elektroliz olayının kullanımına günlük hayattan örnekler verir.

35

Belirteçlerin asit ve bazların tayininde önemli olduğunu kavrar.

Toplam
6

24

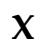

$X$

$X$

$X$

X

X

X

$\mathbf{X}$

X

5

Tablo 1'de verilen 35 soru, fen eğitiminde uzman iki kişi ve bir fen bilimleri öğretmeni tarafından incelenmiştir. Özel yetenekli öğrencilerin sahip oldukları yetenekleri dikkate alınmış ve bu kapsamda altı tane anlama basamağında, 24 tane problem çözme basamağında ve beş tane ise eleştirel düşünme basamağında sorular oluşturulmuştur. Ayrıca uzman görüşleri neticesinde soru maddelerinde olumsuz ifadelerden kaçınılmaya çalışılmış, sorular kısadan uzuna doğru sıralanmış ve çeldiricilerin doğru bir şekilde hazırlanmasına özen gösterilmiştir. Bu kapsamda araştırmacı tarafından hazırlanan soru 24, örnek olarak aşağıda sunulmuştur.

Ali fen bilimleri dersinde ilk 20 elementin metal, yarı metal ve ametal olarak sınıflandırılabileceğini öğrenmiştir. Bu elementlerden atom numarası 3'ün katı olanları kullanarak bir kod oluşturup tabletine şifre koymayı düşünmektedir. Bunun için de atom numarası 3'ün katı olan elementlerden metal olanlara " $X$ ", ametallere ise " $Y$ " harfini yazmıştır. Bu durumda Ali tabletine hangi şifreyi koymuştur?

A) $X Y Y Y X X$ 


\section{B) $X Y Y X Y Y$ \\ C) $Y X X Y Y X$ \\ D) XYYXXX}

Kazanımlara ait sorular alan yazın taraması yapılarak soru havuzundan seçilmiş ve her bir kazanıma ait sorunun hangi kaynaktan alındığı Tablo 2'de sunulmuştur.

Tablo 2. Soruların hazırlanmasında yararlanılan kaynaklar

\begin{tabular}{|c|c|c|c|c|c|}
\hline Soru & $\begin{array}{l}\text { Alıntı yapılan } \\
\text { kaynak }\end{array}$ & $\begin{array}{l}\text { Benzer soru } \\
\text { numarası }\end{array}$ & Soru & $\begin{array}{l}\text { Alıntı yapilan } \\
\text { kaynak }\end{array}$ & Benzer soru numarası \\
\hline 1 & Çakır, 2011 & $\begin{array}{c}\text { Fiziksel ve Kimyasal } \\
\text { Değişim Testi/13. } \\
\text { Soru }\end{array}$ & 19 & $\begin{array}{l}\text { Nur-Aydın, } \\
2018\end{array}$ & $\begin{array}{c}\text { Ön-son Test Sorular/12. } \\
\text { soru }\end{array}$ \\
\hline 2 & Ziyafet, 2008 & Başarı testi/1. Soru & 20 & Gökçek, 2007 & Başarı Testi/2. Soru \\
\hline 3 & Araştırmaci $\mathrm{t}$ & rafından geliştirildi. & 21 & $\begin{array}{c}\text { MEB Kazanım } \\
\text { kavrama testi }\end{array}$ & $\begin{array}{c}\text { Madde ve Endüstri/Test } \\
2 / 5 . \text { soru }\end{array}$ \\
\hline 4 & $\begin{array}{l}\text { MEB Kazanim } \\
\text { Kavrama Testi }\end{array}$ & $\begin{array}{l}\text { Saf maddeler (7. } \\
\text { Sinif)/ 3. soru }\end{array}$ & 22 & Araştırmac & tarafından geliştirildi. \\
\hline 5 & $\begin{array}{l}\text { MEB Kazanım } \\
\text { Kavrama Testi }\end{array}$ & $\begin{array}{l}\text { Fen bilimleri örnek } \\
\text { soruları (8. Sınıf)/ } 15 . \\
\text { soru }\end{array}$ & 23 & Kösece, 2013 & $\begin{array}{c}\text { Günlük hayatla } \\
\text { ilişkilendirme testi/7. Soru }\end{array}$ \\
\hline 6 & Kaşmer, 2011 & Başarı testi(2)/3. soru & 24 & \multicolumn{2}{|c|}{ Araştırmacı tarafından geliştirildi. } \\
\hline 7 & Kingir, 2011 & Başarı testi/5. soru & 25 & \multicolumn{2}{|c|}{ Araştırmacı tarafından geliştirildi. } \\
\hline 8 & Gökçek, 2007 & ÖnBilgi Testi/7. Soru & 26 & \multicolumn{2}{|c|}{ Araştırmacı tarafından geliştirildi. } \\
\hline 9 & Gökçek, 2007 & Başarı Testi/5. Soru & 27 & \multicolumn{2}{|c|}{ Araştırmacı tarafından geliştirildi. } \\
\hline 10 & Araştırmaci $\mathrm{t}$ & rafından geliştirildi. & 28 & LGS, 2018 & $\begin{array}{c}\text { Sayısal, Fen Bilimleri /15. } \\
\text { Soru }\end{array}$ \\
\hline 11 & $\begin{array}{c}\text { Kırmızi-Beyaz } \\
\text { yayıncıllk }\end{array}$ & $\begin{array}{c}\text { Periyodik } \\
\text { sistem/Test } 1 / 1 . \text { Soru }\end{array}$ & 29 & \multicolumn{2}{|c|}{ Araştırmacı tarafından geliştirildi. } \\
\hline 12 & Gökçek, 2007 & $\begin{array}{c}\text { Ön Bilgi Testi/11. } \\
\text { Soru }\end{array}$ & 30 & $\begin{array}{l}\text { Çanta } \\
\text { Yayınları }\end{array}$ & $\begin{array}{c}\text { Kazandıran Yaprak } \\
\text { Test/Asit ve Bazlar 16/9 }\end{array}$ \\
\hline 13 & Gökçek, 2007 & Başarı Testi/17. Soru & 31 & $\begin{array}{l}\text { Nur Aydın, } \\
2018\end{array}$ & $\begin{array}{c}\text { Ön-son Test Sorular/13. } \\
\text { soru }\end{array}$ \\
\hline 14 & Çakır, 2011 & $\begin{array}{l}\text { Fiziksel ve Kimyasal } \\
\text { Değişim Testi/4. Soru }\end{array}$ & 32 & Kıngir, 2011 & Başarı testi/2. soru \\
\hline 15 & Bağcaz, 2009 & Başarı Testi/14. Soru & 33 & Özeken, 2011 & $\begin{array}{c}\text { Asit Baz Konusu Kavram } \\
\text { Testi/13. Soru }\end{array}$ \\
\hline
\end{tabular}




\begin{tabular}{cccccc}
\hline 16 & Bağcaz, 2009 & Başarı Testi/11. Soru & 34 & $\begin{array}{c}\text { MEB Kazanım } \\
\text { kavrama testi }\end{array}$ & $\begin{array}{c}\text { Kimya (12. Sinıf)/Kimya } \\
\text { ve elektrik 7/10. Soru }\end{array}$ \\
17 & Tatlı, 2011 & Başarı Testi/7. Soru & 35 & $\begin{array}{c}\text { LGS, Örnek } \\
\text { sorular, 2019 }\end{array}$ & $\begin{array}{c}\text { Sayıal/Fen Bilimleri/10. } \\
\text { Soru }\end{array}$ \\
18 & Tatlı, 2011 & Başarı Testi/1. Soru & & \\
\hline
\end{tabular}

Tablo 2 incelendiğinde her bir sorunun hangi kaynaklardan alındığı görülmektedir. Örneğin, 1. ve 13. sorular Çakır (2011) tarafından yapılan çalışmadan alındığı, 24. sorunun ise yazar tarafından hazırlandığı görülmektedir. Bununla birlikte çoktan seçmeli başarı testine ait rubriğe doğru cevaplar uygun şekilde seçeneklere dağıtılmıştır. Bu kapsamda, cevabı " $\mathrm{A}$ " olan soru sayısı sekiz , "B" olan soru sayısı 10, "C" olan soru sayısı dokuz ve " $\mathrm{D}$ " olan soru sayısı 7 tane olarak belirlenmiştir. Testte beş tane olumsuz ifade içeren soru yer almakta olup bu soruların soru kökleri belirginleştirilmiştir. Ayrıca öğrencinin soruyu tam olarak anlayabilmesi için soru kökü veya öncüllerde uzman görüşleri ile birlikte düzenlemeler yapılmıştır. Başarı testinin geçerliğini artıracak istatistiksel işlemlerden madde güçlük ve ayırt edicilik indeksleri kontrol edilmiştir.

Tablo 3. Her bir soruya ait madde güçlük indeksi

\begin{tabular}{cccccccc}
\hline Madde & $\begin{array}{c}\text { Güçlük } \\
\text { İndeksi }\end{array}$ & Madde & $\begin{array}{c}\text { Güçlük } \\
\text { İndeksi }\end{array}$ & Madde & $\begin{array}{c}\text { Güçlük } \\
\text { İndeksi }\end{array}$ & Madde & $\begin{array}{c}\text { Güçlük } \\
\text { Índeksi }\end{array}$ \\
\hline P1 & 0.81 & $\mathbf{P 1 0}$ & 0.80 & $\mathbf{P 1 9}$ & 0.62 & $\mathbf{P 2 8}$ & 0.65 \\
P2 & 0.70 & $\mathbf{P 1 1}$ & 0.75 & $\mathbf{P 2 0}$ & 0.75 & $\mathbf{P 2 9}$ & 0.72 \\
P3 & 0.61 & $\mathbf{P 1 2}$ & 0.85 & $\mathbf{P 2 1}$ & 0.90 & $\mathbf{P 3 0}$ & 0.64 \\
$\mathbf{P 4}$ & 0.80 & $\mathbf{P 1 3}$ & 0.68 & $\mathbf{P 2 2}$ & 0.47 & $\mathbf{P 3 1}$ & 0.57 \\
$\mathbf{P 5}$ & 0.78 & $\mathbf{P 1 4}$ & 0.65 & $\mathbf{P 2 3}$ & 0.64 & $\mathbf{P 3 2}$ & 0.72 \\
$\mathbf{P 6}$ & 0.45 & $\mathbf{P 1 5}$ & 0.80 & $\mathbf{P 2 4}$ & 0.58 & $\mathbf{P 3 3}$ & 0.70 \\
$\mathbf{P 7}$ & 0.72 & $\mathbf{P 1 6}$ & 0.64 & $\mathbf{P 2 5}$ & 0.58 & $\mathbf{P 3 4}$ & 0.58 \\
$\mathbf{P 8}$ & 0.87 & $\mathbf{P 1 7}$ & 0.60 & $\mathbf{P 2 6}$ & 0.50 & $\mathbf{P 3 5}$ & 0,38 \\
$\mathbf{P 9}$ & 0.67 & $\mathbf{P 1 8}$ & 0.77 & $\mathbf{P 2 7}$ & 0.57 & & \\
\hline
\end{tabular}

Tablo 3 incelendiğinde; 1 , 4, 8, 10, 12 ve 21 sorularının çok kolay, 2, 3, 5, 7, 9, 11, $13,14,16,17,18,19,20,23,28,29,30,32$ ve 33 sorularinin kolay, 6, 17, 22, 24, 25, 26, $27,31,34$. soruların orta güçlükte 35. sorunun ise zor olduğu görülmektedir. Ayrıca maddelere ait her bir güçlük indeksi toplanıp madde sayısına bölünmüş ve testin ortalama güçlük indeksi hesaplanmıştır. Bu kapsamda teste ait ortalama güçlük 
indeksi 0.68 olarak bulunmuştur (Büyüköztürk, 2018). Bununla birlikte sadece madde güçlük indeksine bakılarak soruların testten çıarılmasına karar verilemediğinden testte bulunan soruların ayırt edicilik indeksleri de hesaplanmıştır. Ayırt edicilik indeksi hesaplanırken her bir soru için üst gruptan soruyu doğru cevaplayanların sayısından alt grupta soruyu doğru cevaplayanların sayısı çıkarılmış, bulunan sonuç üst grupların sayısına bölünmüştür. Bu işlem, Excel programı kullanılarak yürütülmüştür. Her bir soruya r1, r2...r35 kodları verilerek Tablo 4 elde edilmiştir:

Tablo 4. Her bir soruya ait ayırtedicilik indeksi

\begin{tabular}{cccccccc}
\hline Madde & $\begin{array}{c}\text { Ayırt } \\
\text { Edicilik } \\
\text { Indeksi }\end{array}$ & Madde & $\begin{array}{c}\text { Ayırt } \\
\text { Edicilik } \\
\text { Indeksi }\end{array}$ & Madde & $\begin{array}{c}\text { Ayırt } \\
\text { Edicilik } \\
\text { Indeksi }\end{array}$ & Madde & $\begin{array}{c}\text { Ayırt } \\
\text { Edicilik } \\
\text { indeksi }\end{array}$ \\
\hline $\mathbf{r 1}$ & 0.34 & $\mathbf{r 1 0}$ & 0.23 & $\mathbf{r 1 9}$ & 0.46 & $\mathbf{r 2 8}$ & 0.63 \\
$\mathbf{r 2}$ & 0.43 & $\mathbf{r 1 1}$ & 0.37 & $\mathbf{r 2 0}$ & 0.37 & $\mathbf{r 2 9}$ & 0.49 \\
$\mathbf{r 3}$ & 0.43 & $\mathbf{r 1 2}$ & 0.11 & $\mathbf{r 2 1}$ & 0.14 & $\mathbf{r 3 0}$ & 0.60 \\
$\mathbf{r 4}$ & 0.31 & $\mathbf{r 1 3}$ & 0,40 & $\mathbf{r 2 2}$ & 0.60 & $\mathbf{r 3 1}$ & 0.63 \\
$\mathbf{r 5}$ & 0.31 & $\mathbf{r 1 4}$ & 0.46 & $\mathbf{r 2 3}$ & 0.55 & $\mathbf{r 3 2}$ & 0.43 \\
$\mathbf{r 6}$ & 0.34 & $\mathbf{r 1 5}$ & 0.34 & $\mathbf{r 2 4}$ & 0.72 & $\mathbf{r 3 3}$ & 0.55 \\
$\mathbf{r 7}$ & 0.43 & $\mathbf{r 1 6}$ & 0.43 & $\mathbf{r 2 5}$ & 0.49 & $\mathbf{r 3 4}$ & 0.55 \\
$\mathbf{r 8}$ & 0.20 & $\mathbf{r 1 7}$ & 0.63 & $\mathbf{r 2 6}$ & 0.55 & $\mathbf{r 3 5}$ & 0.55 \\
$\mathbf{r 9}$ & 0.31 & $\mathbf{r 1 8}$ & 0.31 & $\mathbf{r 2 7}$ & 0.69 & & \\
\hline
\end{tabular}

Madde ayırt edicilik indeksi değerleri yorumlanırken; her bir soru için elde edilen puan 0.40 ve üzeri ise ayırt ediciliği yüksek, 0.30 ve 0.39 arasında ise orta düzeyde ayırt edici bir sorudur. Bununla birlikte 0.20 ve 0.29 arasında ise sorunun sıkıntılı olduğu ve düzeltilmesi gerektiği, 0.19 ve altında ise o sorunun ayırt ediciliğinin oldukça düşük ve testten çıkarılması gerektiği ifade edilmektedir (Tekin, 2010). Tablo 4 incelendiğinde; 12. ve 21. soruların ayırt edicilik indekslerinin 0.19 değerinden az olduğu tespit edilmiştir. Test sorularının ayırt edici olup olmadığını test etmek için yürütülecek diğer bir test bağımsız gruplar $\mathrm{t}$ testidir. Gerekli istatistiksel işlemler yapılarak elde edilen sonuçlar Tablo 5 'te sunulmuştur.

Tablo 5. Alt ve üst gruplara yönelik $t$ Testi sonuçları

\begin{tabular}{|c|c|c|c|c|c|c|c|c|c|c|c|c|c|}
\hline Soru & Grup & $\mathbf{N}$ & $X$ & $\mathrm{~s}$ & $\mathbf{t}$ & p & Soru & Grup & $\mathbf{N}$ & $X$ & s & $\mathbf{t}$ & $\mathbf{p}$ \\
\hline \multirow{2}{*}{1} & ÜST & 34 & 9706 & 1715 & \multirow{2}{*}{4,115} & \multirow{2}{*}{,000 } & \multirow{2}{*}{19} & ÜST & 34 & ,8824 & 3270 & \multirow{2}{*}{5,077} & \multirow{2}{*}{,000 } \\
\hline & ALT & 35 & 6000, & 4970 & & & & ALT & 35 & ,3714 & 4902 & & \\
\hline
\end{tabular}




\begin{tabular}{|c|c|c|c|c|c|c|c|c|c|c|c|c|c|}
\hline \multirow{2}{*}{2} & ÜST & 34 & 9412 & 2388 & \multirow{2}{*}{4,750} & \multirow{2}{*}{,000 } & \multirow{2}{*}{20} & ÜST & 34 & 9706 & 1715, & \multirow{2}{*}{4,393} & \multirow{2}{*}{,000 } \\
\hline & ALT & 35 & 4857 & ,5070 & & & & ALT & 35 & ,5714 & 5021 & & \\
\hline \multirow{2}{*}{3} & ÜST & 34 & ,8529 & 3594 & \multirow{2}{*}{4,326} & \multirow{2}{*}{,000 } & \multirow{2}{*}{21} & ÜST & 34 & 1,000 & 0000 & \multirow{2}{*}{2,614} & \multirow{2}{*}{011} \\
\hline & ALT & 35 & 4000 & 4970 & & & & ALT & 35 & ,8286 & 3823 & & \\
\hline \multirow{2}{*}{4} & ÜST & 34 & 9412 & 2388 & \multirow{2}{*}{3,617} & \multirow{2}{*}{,001 } & \multirow{2}{*}{22} & ÜST & 34 & 7941 & 4104 & \multirow{2}{*}{6,523} & \multirow{2}{*}{,000 } \\
\hline & ALT & 35 & 6000 & ,4970 & & & & ALT & 35 & 1714 & 3823 & & \\
\hline \multirow{2}{*}{5} & ÜST & 34 & ,9706 & 1715, & \multirow{2}{*}{3,845} & \multirow{2}{*}{,000 } & \multirow{2}{*}{23} & ÜST & 34 & 9412 & 2388 & \multirow{2}{*}{6,108} & \multirow{2}{*}{,000 } \\
\hline & ALT & 35 & 6286 & 4902 & & & & ALT & 35 & ,3714 & 4902 & & \\
\hline \multirow{2}{*}{6} & ÜST & 34 & 6471 & 4850 & \multirow{2}{*}{3,181} & \multirow{2}{*}{,002 } & \multirow{2}{*}{24} & ÜST & 34 & ,9706 & 1715, & \multirow{2}{*}{9,438} & \\
\hline & ALT & 35 & 2857 & 4583 & & & & ALT & 35 & 2286 & 4260 & & , 000 \\
\hline & ÜST & 34 & 9706 & 1715 & & & & ÜST & 34 & ,8529 & 3594 & & \\
\hline 7 & ALT & 35 & ,5143 & 5070 & 4,977 & ,000 & 25 & ALT & 35 & 3429 & 4815, & 4,974 & ,000 \\
\hline & ÜST & 34 & 1,000 & 0000, & & & & ÜST & 34 & 7941 & 4104 & & \\
\hline 0 & ALT & 35 & 7714 & ,4260 & 0 & , & 20 & ALT & 35 & 2286 & 4260 & ט, &, 000 \\
\hline & ÜST & 34 & ,8529 & 3594 & & & & ÜST & 34 & 9412 & 2388 & & \\
\hline 3 & ALT & 35 &, 5143 & ,5070 & 3,192 & , & 27 & ALT & 35 & 2286 & ,4260 & 0,030 & , \\
\hline & ÜST & 34 & 9412 & 2388 & & & & ÜST & 34 & 1,0000 & 0000 & & \\
\hline 10 & ALT & 35 & 6857 & ,4710 & 2,829 & , 006 & 28 & ALT & 35 & 3429 & 4815 & 1,900 & , 000 \\
\hline & ÜST & 34 & ,9706 & 1715, & & & & ÜST & 34 & 1,0000 & 0000 & & \\
\hline 11 & ALT & 35 & ,5714 & ,5021 & טרנוד &, 000 & 23 & ALT & 35 & 4857 & ,5070 & , &, 000 \\
\hline & ÜST & 34 & 9412 & 2388 & & & & ÜST & 34 & 9706 & 1715, & & \\
\hline 12 & ALT & 35 & 8000 & 4058 & $1, / 34$ & ,084 & 30 & ALT & 35 & 3429 & 4815, & 8,170 & , \\
\hline & ÜST & 34 & 9118 & 2879 & & & & ÜST & 34 & 9118 & 2879 & & \\
\hline 10 & ALT & 35 & ,485 & ,5070 & 4,275 & ,000 & 31 & ALT & 35 & 2571 & 4434 & 7,200 & , \\
\hline & ÜST & 34 & 9118 & 2879 & & & & ÜST & 34 & 9706 & 1715, & & \\
\hline 14 & ALT & 35 & 4286 & ,5021 & 4,000 & , & 32 & ALT & 35 & ,5143 & ,5070 & ונוד & , \\
\hline
\end{tabular}




\begin{tabular}{|c|c|c|c|c|c|c|c|c|c|c|c|c|c|}
\hline \multirow{2}{*}{15} & ÜST & 34 & 9706 & 1715 & \multirow{2}{*}{4,115} & \multirow{2}{*}{,000 } & \multirow{2}{*}{33} & ÜST & 34 & 1,000 & ,0000 & \multirow{2}{*}{6,635} & \multirow{2}{*}{,000 } \\
\hline & ALT & 35 & 6000 & 4970 & & & & ALT & 35 & 4286 & ,5021 & & \\
\hline \multirow[b]{2}{*}{16} & ÜST & 34 & ,8824 & 3270 & \multirow[b]{2}{*}{4,434} & \multirow[b]{2}{*}{,000 } & \multirow[b]{2}{*}{34} & ÜST & 34 & ,8824 & ,3270 & \multirow[b]{2}{*}{5,803} & \multirow[b]{2}{*}{,000 } \\
\hline & ALT & 35 & 4286 & ,5021 & & & & ALT & 35 & 3143 & 4710 & & \\
\hline \multirow{2}{*}{17} & ÜST & 34 & 9412 & 2388 & \multirow{2}{*}{7,417} & \multirow{2}{*}{,000 } & \multirow{2}{*}{35} & ÜST & 34 & 6765, & ,4748 & \multirow{2}{*}{5,766} & \multirow{2}{*}{, 000} \\
\hline & ALT & 35 & 2857 & 4583 & & & & ALT & 35 & 1143, & 3228 & & \\
\hline \multirow[b]{2}{*}{18} & ÜST & 34 & 1,000 & 0000 & \multirow[b]{2}{*}{4,150} & \multirow[b]{2}{*}{,000 } & & & & & & & \\
\hline & ALT & 35 & 6571 & 4815 & & & & & & & & & \\
\hline
\end{tabular}

Tablo 5'te her bir soru için $t$ testi uygulanarak alt ve üst gruplar karşılaştııılmıştır. Ayırt edicilik indeksleri 0.19 değerinden küçük çıkan 12. ve 21. sorular için Tablo 5'te yer alan $\mathrm{p}$ değerleri incelenmiş ve soruların anlamlılık değerleri 12. soru için .084, 21. soru için .011 değerleri bulunmuştur. Bu kapsamda 12. sorunun $p$ değeri .05 anlamlılık değerinden büyük olup bu soru için alt grup ve üst gruptan elde edilen puanlar arasında anlamlı bir farklılık olmadığ 1 yorumuna varılabilir.

Araştırmada yapı geçerliğini sağlamak için açımlayıcı faktör analizi yürütülmüştür. Testin soyut bir kavramı ölçme derecesini gösteren yapı geçerliliğinde (Büyüköztürk, 2018) verilerin faktör analizine uygunluğu için KaiserMayer- Olkin (KMO) katsayısı ile Barlett's küresellik testi dikkate alınır ve KMO endeksinin .60 değerinden yüksek olması önerilir (Tabachnick ve Fidell, 2013). Bu kapsamda gerekli istatistiksel işlemler yapılmış ve KMO değeri Tablo 6'da sunulmuştur:

Tablo 6. Başarı testi için KMO değeri

\begin{tabular}{ll}
\hline Kaiser-Meyer-Olkin Measure of Sampling Adequacy. &, 748 \\
\hline Approx. Chi-Square & 2571.992 \\
Bartlett's küresellik testi df & 528 \\
Anlamlılık (Sig.) &, 000 \\
\hline
\end{tabular}

Tablo 6 incelendiğinde $\mathrm{KMO}$ değerinin .60 değerinden yüksek çıktığ1 görülmekte ve bu durumda faktör analizinin yapılmasının uygun olduğu yorumuna varılabilir. Ayrıca Bartlett'in küresellik testinde anlamlılık değerinin .000 çıması verilerin normal dağılım gösterdiğini desteklemektedir. Verilerin faktör analizi sonucu kaç faktörden oluştuğunu belirlemek için çizgi grafiği ve öz değer kullanılmış ve başarı testine ait toplam varyans değerleri Tablo 7 'de sunulmuştur. 
Tablo 7. Toplam varyans değerleri

\begin{tabular}{cccc}
\hline Faktör & Özdeğer & Varyansın Yüzdesi & Toplam Yüzde \\
\hline 1 & 7.150 & 21.667 & 21.667 \\
2 & 2.024 & 6.134 & 27.801 \\
3 & 1.828 & 5.538 & 33.339 \\
4 & 1.722 & 5.218 & 38.558 \\
5 & 1.609 & 4.875 & 43.433 \\
\hline
\end{tabular}

Tablo 7'de özdeğeri 1'den büyük olan faktörler yer almaktadır. Bu kapsamda faktör sayısına karar vermek için 1 ya da daha fazla özdeğere sahip bileşenler dikkate alınır (Pallant, 2016). Dolayısıyla test beş faktör altında toplanmış ve bu faktörler test sorularını \% 43,433'nü kapsamaktadır. Bununla birlikte Şekil 1'de başarı testine yönelik Scree Plot grafiği verilmiştir:

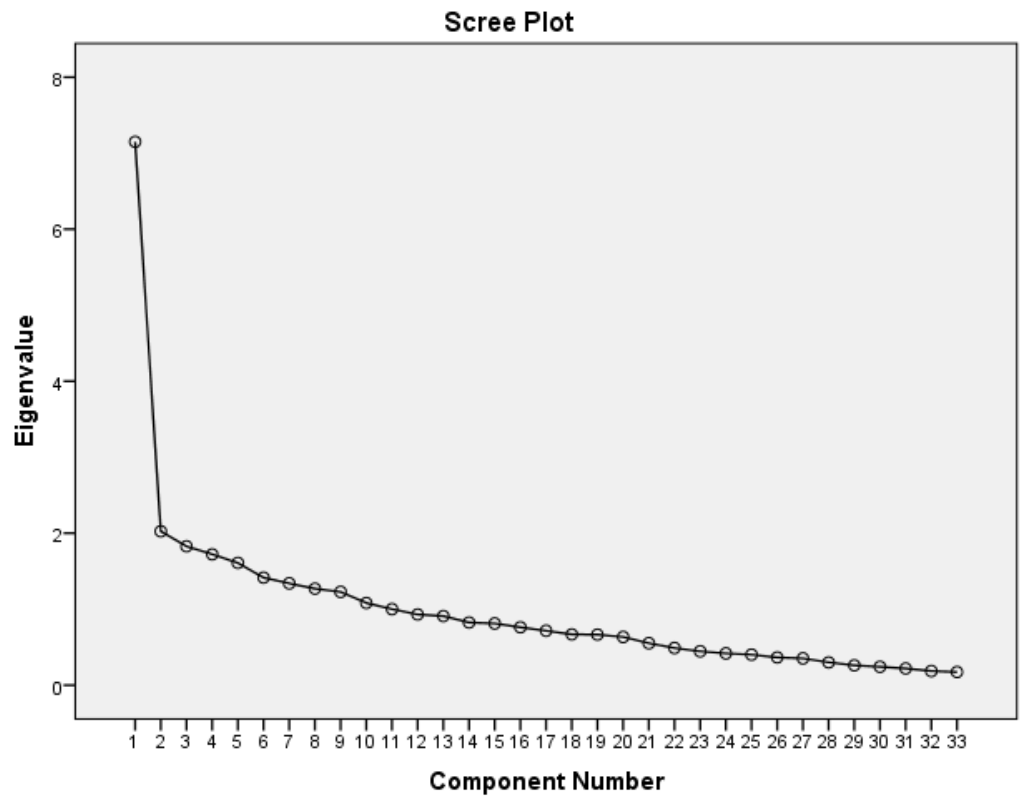

Şekil 1. Scree Plot Grafiği

Şekil 1 incelendiğinde, birinci faktörden sonra hızlı bir düşüş yaşandığg eğimin beş faktörden sonra ise giderek düzleştiği görülmektedir. Bu noktadan sonra faktörlerin varyansa katkısının az olduğu söylenebilir (Çokluk, Şekercioğlu ve Büyüköztürk, 2010) ve Scree Plot grafiği beş faktöre işaret ettiği yorumuna varılabilir. Soruların bulunduğu faktörler ve katsayıları Tablo 8 ' de sunulmuştur: 
Tablo 8. Teste yönelik faktör yük değgerleri

\begin{tabular}{|c|c|c|c|c|c|}
\hline \multirow{2}{*}{ Madde } & \multicolumn{5}{|c|}{ Faktörler } \\
\hline & Faktör 1 & Faktör 2 & Faktör 3 & Faktör 4 & Faktör 5 \\
\hline 1 & ,464 & & & & \\
\hline 23 & ,548 & & & & \\
\hline 3 &, 513 & & & & \\
\hline 4 & ,442 & & & & \\
\hline 20 & ,415 & & & & \\
\hline 2 & 645 & & & & \\
\hline 28 & ,444 & & & & \\
\hline 29 & ,598 & & & & \\
\hline 30 & ,596 & & & & \\
\hline 31 & ,472 & & & & \\
\hline 35 & ,418 & & & & \\
\hline 17 & &, 564 & & & \\
\hline 22 & & ,518 & & & \\
\hline 24 & & ,510 & & & \\
\hline 25 & &, 511 & & & \\
\hline 26 & & ,588 & & & \\
\hline 27 & & 663 & & & \\
\hline 32 & & ,417 & & & \\
\hline 34 & & 762 & & & \\
\hline 5 & & & ,544 & & \\
\hline 8 & & & 665 & & \\
\hline 14 & & & 605 & & \\
\hline 15 & & & ,439 & & \\
\hline 19 & & & ,468 & & \\
\hline 28 & & & 446 & & \\
\hline 7 & & & & ,526 & \\
\hline 11 & & & & ,540 & \\
\hline 13 & & & & 723 & \\
\hline 6 & & & & &, 565 \\
\hline 9 & & & & & ,487 \\
\hline 18 & & & & &, 538 \\
\hline
\end{tabular}


Faktör analizinde 0.40 yük değerinden küçük olan sorular ihmal edilmiş ve faktör analizinden sonra her bir faktördeki sorular, araştırmacı tarafından incelenmiştir. İnceleme sonucu faktörler isimlendirilmiştir. Bu kapsamda birinci faktör elementler ve özellikleri, ikinci faktör elektroliz olayı ve gümüş halojenürler, üçüncü faktör fiziksel ve kimyasal değişim, dördüncü faktör $p H$ kavramı ve beşinci faktör asit ve bazlar şeklinde kodlanmıştır.

\section{Başarı Testine Yönelik Güvenirlik Çalışması}

Ölçme sonuçlarının tesadüfî hatalardan arınık olma derecesini ifade eden güvenirlik ayrıca ölçme sonuçlarının kararlı ve tutarlı olması anlamına da gelmektedir (Çepni, vd., 2012). Güvenirlik hesaplamasında KR 20, KR 21 ve Cronbach alfa hesaplamaları gibi birçok istatistiksel yöntem vardır. Genel olarak yanlış yanıt için sıfır, doğru yanıt için bir değerinin kullanıldığı testlerde Cronbach alfa veya KR 20 hesaplamaları tercih edilir (Atılgan, 2013) ve elde edilen değerin .70 ve üzerinde olması beklenir (De Vellis, 2012). Bu çalışmada da öğrencilerin başarı testinden aldıkları puanların güvenirliğini belirlemek için KR 20 değeri hesaplanmış olup belirlenen değerler Tablo 9'da sunulmuştur:

Tablo 9. KR20 güvenirlik katsayısı değeri

\begin{tabular}{ccc}
\hline KR 20 & KR 20 Based on Standardized Items & N \\
\hline 0.876 & 0.874 & 35 \\
\hline
\end{tabular}

Tablo 9 incelendiğinde, başarı testine ait güvenirlik katsayısının 0.87 olduğu görülmektedir. Buradan hareketle başarı testinin güvenilir olduğu sonucu yapılabilir. Her bir sorunun güvenirlik katsayısına etkisini gösteren değerler Tablo 10'da verilmiştir.

Tablo 10. Soruların güvenirlik katsayısına etkisi

\begin{tabular}{cccc}
\hline Soru & KR 20 if Item Deleted & Soru & KR 20 if Item Deleted \\
\hline $\mathbf{1}$ &, 874 & $\mathbf{1 9}$ &, 873 \\
$\mathbf{2}$ &, 872 & 20 &, 871 \\
$\mathbf{3}$ &, 873 & 21 &, 875 \\
$\mathbf{4}$ &, 877 & 22 &, 871 \\
$\mathbf{5}$ &, 874 & 23 &, 871 \\
$\mathbf{6}$ &, 871 & 24 &, 869 \\
7 &, 871 & 25 &, 872 \\
8 &, 874 & 26 &, 871
\end{tabular}


9

10

11

12

13

14

15

16

17

18
, 876

, 875

, 872

, 886

, 874

, 872

, 874

, 873

, 870

, 876
27

28

29

30

31

32

33

34

35
,868

,868

, 869

, 870

, 870

, 871

, 870

, 869

, 872

Tablo 10'da her bir soru çıkarıldığında güvenirlik katsayısındaki oranın ne olacağ1 verilmiştir. Bu kapsamda ayırt ediciliği düşük çıkan, alt ve üst grupların elde ettiği puanlar arasında anlamlı bir farklılığın olmadığı 12. soru testten çıkarıldığında testin güvenirlik katsayı değerinin yükseldiği görülmektedir. Bu bulgu neticesinde 12. sorunun testten çıarılmasına karar verilmiştir. Tüm bu değerlendirmeler ışığında, geçerlik ve güvenirlik çalışmalarıyla birlikte BİLSEM'de BYF programında öğrenim gören özel yetenekli öğrencilerinin fen bilimleri madde ve değişim ünitesine yönelik bir başarı testi geliştirilmiştir.

\section{Sonuç ve Tartışma}

$\mathrm{Bu}$ çalışmada Bilim ve Sanat Merkezi'nde BYF programında öğrenimlerine devam eden özel yetenekli öğrencilerin fen bilimleri madde ve değişim ünitesindeki başarılarını belirlemek için geçerli ve güvenilir bir başarı testinin geliştirilmesi amaçlanmıştır. Yürütülen analiz çalışmaları sonucunda geliştirilen testin özellikleri şu şekildedir:

- Testin adı: Madde ve Değişim Ünitesi Başarı Testi (MDÜBT).

- Soru sayisi: 34

- Kuder Richardson-20 (KR-20) değeri: 0.876

- Testin ortalama madde güçlük değeri: 0.68

- Testi oluşturan faktörlerin sayısı: 5

- Testi oluşturan faktörlerin adı: Elementler ve özellikleri, elektroliz olayı ve gümüş halojenürler, fiziksel ve kimyasal değişim, pH kavramı, asit ve bazlar.

Başarı testi geliştirme sürecinde bir dizi adımlar izlenerek çalışma yürütülmüştür. Bu süreçte öncelikle çalışmanın amacı belirlenmiş ve kazanımlara ait 
en az iki soru, alan yazın taraması yapılarak soru havuzuna eklenmiştir. Fen eğitiminde uzman bir kişiden devamlı dönütler alınarak teste uygulama öncesi son hali verilmeye çalışılmıştır. Bu süreçte kazanımlar, kazanıma yönelik sorular, belirtke tablosu ve rubrik uygun bir şekilde hazırlanmıştır. Ayrıca kazanımların belirlenmesinde taksonomik kurallara dikkat edilmiş, güçlük ve ayırt edicilik indeksleri ile güvenirlik katsayı değerleri hesaplanmıştır. Yürütülen bu işlemler dikkate alındığında alan yazında başarı testi geliştirme sürecinde benzer çalışmaların yapıldığ1 görülmektedir (Çalık ve Ayas, 2003; Çardak ve Selvi, 2018; Ersoy ve Bayraktar, 2018; Evrekli, İnel, Balım ve Kesercioğlu, 2009; Güneş-Yazar ve Nakipoğlu, 2019). Dolayısıyla alan yazında başarı testi geliştirme çalışmaları ile mevcut çalışmada yürütülen işlemler benzerlik göstermektedir.

Başarı testi geliştirme sürecinde kapsam geçerliğini sağlamak adına madde güçlük (Tablo 3) ve ayırt edicilik indeksleri (Tablo 4) hesaplanmıştır. Ayrıca test sorularının ayırt edici olup olmadığını belirlemek için bağımsız gruplar $t$ testi yürütülmüştür. Bu analizler sonucunda 35 soruluk testte yer alan 12. sorunun kolay, ayırt ediciliğinin düşük ve bu soruya cevap veren alt ve üst grupların elde ettiği puanların arasında anlamlı bir farklılığın olmadığı belirlenmiştir. Aynı zamanda bu sorunun testten çıkarılması durumunda güvenirlik katsayı değerinin yükseldiği tespit edilmiştir (Tablo 10). Elde edilen tüm bu bulgular neticesinde 12. sorunun testten çıkarılmasına yönelik karar verilmiştir. Pilot çalışma sonucu testte bulunan maddelerin çıkarılıp çıkarılmamasına karar verme sürecinde alan yazında benzer çalışmaların yapıldı̆̆ı da görülmektedir (Hazır-Bıkmaz, 2002; Taşdemir, 2004).

Bu çalışmada, yapı geçerliğini sağlamak adına açımlayıcı faktör analizi (AFA) yürütülmüştür. AFA sonucunda testin beş faktörden oluştuğu belirlenmiştir (Tablo 8). Her faktörde yer alan soru maddeleri incelenmiş ve elementler ve özellikleri, elektroliz olayı ve gümüş halojenürler, fiziksel ve kimyasal değişim, pH kavramı ve asit ve bazlar şeklinde faktörler isimlendirilmiştir. Ayrıca güvenirlik çalışmaları sonucunda KR20 güvenirlik katsayısı .876 olarak hesaplanmıştır. Hesaplanan güvenirlik katsayısının 0.60 değerinden büyük olmasından dolayı testten alınan puanların güvenilir olduğu yorumu yapılabilir (Can, 2014). Sonuç olarak özel yetenekli öğrencilerin eğitim gördüğü BİLSEM'lerde yürütülen fen bilimleri dersi madde ve değişim ünitesinin öğrenimine ilişkin geliştirilen başarı testinin geçerli ve güvenilir bir test olduğu söylenebilir ve bu başarı testi özel yetenekli öğrencilerin Madde ve Değişim ünitesindeki bilgi seviyelerini incelemek için öğretmenler ve araştırmacılar tarafından kullanılabilir. Ayrıca fen bilimleri dersi öğretim programı incelendiğinde 8. sınıf öğrencilerinin Madde ve Endüstri ünitesinde başarılarını belirlemek için geliştirilen testin kullanılabileceği de önerilmektedir. 


\section{Kaynaklar}

Açıkgöz, M. \& Karslı, F. (2015). Alternatif ölçme-değerlendirme yaklaşımları kullanılarak iş ve enerji konusunda geliştirilen başarı testinin geçerlilik ve güvenirlik analizi. Amasya Üniversitesi Ĕ̆itim Fakültesi Dergisi, 4(1), 1-25.

Akbulut, H. İ. ve Çepni, S. (2013). Bir üniteye yönelik başarı testi nasıl geliştirilir? :İlköğretim 7. sinıf kuvvet ve hareket ünitesine yönelik bir çalışma. Amasya Üniversitesi Ĕ̆itim Fakültesi Dergisi, 2(1), 18-44.

Atılgan, H. (Ed.) (2013). Eğitimde ölçme ve değerlendirme (6. Baskı). Ankara: Anı Yayıncılık.

Ayvacı, H. Ş. \& Durmuş, A. (2016). Bir başarı testi geliştirme çalışması: Isı ve sıcaklık başarı testi geçerlik ve güvenirlik araştırması. Ondokuz Mayıs Üniversitesi Eğitim Fakültesi Dergisi, 35(1), 87-102.

Ayverdi, L. (2018). Özel yetenekli öğrencilerin fen eğitiminde teknoloji, mühendislik ve matematiğin kullanımı: Fetemm yaklaşımı. Doktora Tezi, Balıkesir Üniversitesi, Fen Bilimleri Enstitüsü, Balıkesir.

Balcı, E. \& Tekkaya, C. (2000). Ölçme ve değerlendirme tekniklerine yönelik bir ölçeğin geliştirilmesi. Hacettepe Üniversitesi Ĕ̆itim Fakültesi Dergisi, 18, 42-50.

Bağcaz, E. (2009). Sorgulayıcı öğretim yönteminin öğrencilerin akademik başarısı ve fen ve teknoloji dersine yönelik tutumuna etkisi. Yüksek Lisans Tezi, Sakarya Üniversitesi, Fen Bilimleri Enstitüsü, Sakarya.

Bingöl, A. \& Halisdemir, N. (2017). Üniversite öğrencilerinin temel bilgi teknolojileri dersine yönelik akademik başarı testi geliştirme çalışması. The Journal of Academic Social Science Studies, 54, 541-554.

Birgili, B. (2014). Open Ended Questions As An Alternative To Multiple Choice: Dilemma In Turkish Examination System. Middle East Technical University.

Büyüköztürk, Ş. (2018). Sosyal Bilimler İçin Veri Analizi El Kitabı (24. Baskı), Ankara: Pegem Yayıncilik.

Büyüköztürk, S., Kılıç Çakmak, E., Akgün, O. E., Karadeniz, S. \& Demirel, F. (2014). Bilimsel araştırma yöntemleri (16. Baskı). Pegem Akademi Yayıncılık, Ankara.

Can, A. (2014). SPSS ile bilimsel araştırma sürecinde nicel veri analizi (2. Bask1). Ankara: Pegem A Yayıncilik.

Çakır, B.Z.O. (2011). The influence of argumentation based instruction on sixth grade students" attitudes toward science, conceptual understandings of physical and chemical change topic and argumentativeness. Yüksek Lisans Tezi, Ortadoğu Teknik Üniversitesi, İlköğretim Fen ve Matematik Alanları Eğitimi Bölümü, Ankara.

Çalık, M. \& Ayas, A. (2003). Çözeltilerde kavram başarı testi hazırlama ve uygulama. Pamukkale Üniversitesi Eğitim Fakültesi Dergisi, 2(14), 1-17.

Çardak, Ç. S. \& Selvi, K. (2018). Öğretim ilke ve yöntemleri dersi için başarı testi geliştirme süreci. Akdeniz Ĕ̆gitim Araştırma Dergisi,12(26), 379-406.

Çepni, S., Bayrakçeken, S., Yılmaz, A., Semerci, Ç., Köse, E., Sezgin, F., Demircioğlu, F. \& Gündoğdu, K. (2012). Ölçme Değerlendirme (5. Baskı). Pegem A yayıncılık. 
Çokluk, Ö., Şekercioğlu, G. \& Büyüköztürk, Ş. (2010). Sosyal bilimler için çok değ işkenli istatistik: SPSS ve LISREL uygulamaları. Ankara: Pegem Akademi.

De Vellis, R. F. (2012). Scale development: Theory and applications (3. ed.). Thousand Oaks, California: Sage.

Ersoy, E. \& Bayraktar. G. (2018). İlkokul 4. sinıf matematik dersi "ondalık gösterim" alt öğrenme alanına ilişkin başarı testi geliştirilmesi. Buca Eğitim Fakültesi Dergisi, 46, 240-266.

Evrekli, E., İnel, D., Balım, A. G. \& Kesercioğlu, T. (2009). Fen öğretmen adaylarına yönelik yapılandırıcı yaklaşım tutum ölçeği: geçerlik ve güvenirlik çalışması. Türk Fen Ĕ̈itim Dergisi, 6(2),134-148.

Gökçek, N. (2007). İlköğretim 8. sını öğrencilerinin asit baz konusundaki başarılarına çoklu zeka kuramının etkisinin araştırılması. Yüksek Lisans Tezi, Gazi Üniversitesi, Eğitim Bilimleri Enstitüsü, Ankara.

Gülen, S. \& Demirkuş, N. (2014). “Güneş sistemi ve ötesi: Uzay bilmecesi” ünitesinde, görsel materyalin öğrenci başarısına etkisi. YYü Eğitim Fakültesi Dergisi, 11(1), 1-19.

Güler, N. (2017). Eğitimde Ölçme ve Değerlendirme (10.Baskı). Ankara: Pegem Akademi

Gültekin, M. (2017). Program geliştirmeye ilişkin temel kavramlar, Behçet Erol ve Taha Yazar (Editörler). Eğitimde program geliştirme ve değerlendirme (1. Baskı). Ankara: Pegem Akademi.

Güneş-Yazar, O. \& Nakipoğlu, C. (2019). Development of achievement test about unit of "nature and chemistry" for 9th grades: A validity and reliability study. Necatibey Faculty of Education Electronic Journal of Science and Mathematics Education 13(1), 76-104.

Güngörmez, H.G. \& Akgün, A. (2018). Ortaokul öğrencilerinin fen bilimleri dersindeki kuvvet ve enerji ünitesine yönelik akademik başarı testi geliştirme çalışması. Diyalektolog Ulusal Sosyal Bilimler Dergisi, 18, 85-99.

Fraenkel, J. K. \& Wallen, N. E. (1996). How to design and evaluate research in education (3. edition). New York: McGraw-Hill, Inc.

Haladyna, T. M. (1997). Writing test items to evaluate higher order thinking. Allynand Bacon: Needham Heights, MA.

Hazır-Bıkmaz, F. (2002). Fen eğitiminde öz-yeterlik inancı ölçeği. Eğitim Bilimleri ve Uygulama, 1(2), 197-210.

Karasar, N. ( 1995). Bilimsel Araştırma Yöntemi. Ankara: 3A Araştırma Eğitim Danışmanlık Ltd.

Kaşmer, N. (2011). Ortaöğretim 9. sınıf kimya dersi kimyasal değişim ünitesinde ön düzenleyici kullanımının öğrenci başarısına etkisi. Yüksek Lisans Tezi, Balıkesir Üniversitesi, Fen Bilimleri Enstitüsü, Balıkesir.

Kayışdağ, E. \& Melekoğlu, M.A. (2019). Bilim ve sanat merkezlerinin eğitim programlarının öğrenci görüşlerine dayalı olarak değerlendirilmesi. Eskişehir Osmangazi Üniversitesi Sosyal Bilimler Dergisi, 20 (Özel Sayı), 175-202. 
Keçeci, G., Yıldırım, P. \& Kırbağ Zengin, F. (2019). Sistemler akademik başarı testi: Geçerlik ve güvenirlik çalışması. Ulusal Eğitim Akademisi Dergisi (UEAD), 3(1), 96-114.

Kempa, R. (1986). Assessment in Science. Cambridge University Press, Cambridge, London.

Kıngır, S. (2011). Argümantasyon tabanlı bilim öğrenme yaklaşımının öğrencilerin kimyasal değişim ve karışım kavramlarını anlamalarını sağlamada kullanılması. Doktora Tezi, Ortadoğu Teknik Üniversitesi, Ortaöğretim Fen ve Matematik Alanları Eğitimi Bölümü, Ankara.

Kızkapan, O. \& Bektaş O. (2018). Fen eğitiminde başarı testi geliştirilmesi: hücre bölünmesi ve kalıtım örneği. Maarif Mektepleri Uluslararası Eğitim Bilimleri Dergisi, 2(1), 1-18.

Klufa, J. (2015). Multiple Choice Question Tests-Advantages and Disadvantages.

Kösece, E. (2013). 6. sını öğrencilerinin fiziksel ve kimyasal değişim konusunu günlük hayat ile ilişkilendirmeleri. Abant İzzet Baysal Üniversitesi, Eğitim Bilimleri Enstitüsü, Bolu.

Küçükahmet, L. (2002). Öğretimde planlama ve değerlendirme (13. Baskı). Ankara: Nobel Yayın Dağıtım.

MEB. (2016c). Bilim ve Sanat Merkezleri Yönergesi [Online]. (12 Haziran 2019), https://orgm.meb.gov.tr/meb_iys_dosyalar/2016_10/07031350_bilsem_yonergesi. pdf.

MEB. (2017a). 2017- 2018 bilim ve sanat merkezleri öğrenci tanılama kllavuzu [Online]. (12 Haziran 2019), https://orgm.meb.gov.tr.

Nur-Aydın, Ş.Z. (2018). Fen bilgisi dersi öğretiminde sanal laboratuvar uygulamasının kullanılması ve değerlendirilmesi. Yüksek Lisans Tezi, İstanbul Üniversitesi, Eğitim Bilimleri Enstitüsü, İstanbul.

Ogan-Bekiroğlu, F. (2004). Ne kadar Başarılı?, Klasik ve Alternatif Ölçme Değerlendirme Yöntemleri ve Fizikte Uygulamalar (1. baskı). Ankara: Nobel Yayın Dağıtım

Öksüz, Y. \& Güven Demir, E. (2019). Açık uçlu ve çoktan seçmeli başarı testlerinin psikometrik özellikleri ve öğrenci performansı açısından karşılaştırılması. Hacettepe Üniversitesi Ĕ̆itim Fakültesi Dergisi, 34(1), 259-282.

Özeken, Ö.F. (2011). Probleme dayal öğrenmenin asit-baz konusunun öğretiminde etkinliğinin incelenmesi. Doktora Tezi, Atatürk Üniversitesi, Eğitim Bilimleri Enstitüsü, Erzurum.

Pallant J. (2016). SPSS kullanma kılavuzu SPSS ile adım adım veri analizi. (S.Balcı ve B.Ahi, Çeviri). Ankara: Anı Yayıncılık.

Samaie, M. \& Khosravian, F. (2014). Achievement test development and validation: A measure of reading comprehension strategies for Iranian learners of English. International Journal of Linguistics, 6(2), 12-22.

Saraç, H. (2018). Fen bilimleri dersi 'maddenin değişimi' ünitesi ile ilgili başarı testi geliştirme: Geçerlik ve güvenirlik çalışması. Abant Izzet Baysal Üniversitesi Eğitim Fakültesi Dergisi, 18(1), 416-445.

Sarıtaş, E., Şahin, Ü. \& Çatalbaş, G. (2019). Velilerin gözüyle BİLSEM. Ĕ̆itimde Nitel Araştırmalar Dergisi, 7(1), 114-133. 
Singh, C. \& Rosengrant, D. (2003). Multiple-choice test of energyand momentum concepts. American Association of Physics Teachers, 71(6), 607-617.

Şimşek, A. (2009). Öğretim Tasarımı (1. baskı), Ankara: Nobel Yayın Dağıtım.

Tabachnick, B.G. \& Fidell, L. S. (2013). Using multivariate statistics (Sixth edition). New Jersey: Pearson Prentice Hall.

Taşdemir, A. (2004). Fen bilgisi öğretmenliği kimya laboratuvarı dersinde çözeltiler konusunun öğrenilmesinde işbirlikli öğrenme yönteminin etkileri. Yüksek lisans tezi, Gazi Üniversitesi, Ankara.

Tatlı, Z. (2011). Ortaöğretim 9. sınıf kimyasal değissimler ünitesine yönelik sanal kimya laboratuvarı deneylerinin geliştirilmesi uygulanması ve değerlendirilmesi. Doktora Tezi, Karadeniz Teknik Üniversitesi, Eğitim Bilimleri Enstitüsü, Trabzon.

Tekin, H. (2010). Eğitimde ölçme ve değerlendirme (20. Bask1). Ankara: Yarg1 Yayınevi.

Turgut, M.F. (1983). Eğitimde ölçme ve değerlendirme metotları (2. Baskı). Ankara: Saydam Matbaacilik.

Turgut, M. F. \& Baykul, Y. (2012). Ĕ̆itimde ölçme ve değerlendirme (4. Baskı). Ankara: Pegem Akademi

Ziyafet, E. (2008). Fen ve teknoloji dersinde periyodik çizelgenin öğretiminde 5E modelinin öğrenci tutum ve başarısına etkisi. Yüksek Lisans Tezi, Gazi Üniversitesi, Eğitim Bilimleri Enstitüsü, Ankara. 